\title{
INVESTIGASI FAKTOR-FAKTOR YANG MEMPENGARUHI PARTISIPASI DISKUSI ONLINE: STUDI KASUS STUDENT-CENTERED E-LEARNING ENVIRONMENT MAGISTER TEKNOLOGI INFORMASI UNIVERSITAS INDONESIA
}

\author{
Meyer E. Sihotang ${ }^{1}$, Widijanto Satyo Nugroho ${ }^{2}$ \\ ${ }^{1}$ Magister Teknologi Informasi-Universitas Indonesia \\ Jl. Salemba Raya No.4, Jakarta Pusat, Indonesia \\ ${ }^{2}$ Fakultas Ilmu Komputer-Universitas Indonesia \\ Kampus UI Depok, Indonesia 16424
}

E-mail: meyer.sihotang@yahoo.com, wnugroho@cs.ui.ac.id

\begin{abstract}
The use of e-Learning in Universitas Indonesia has been regulated by The Official Decree of The Rector of the Universitas Indonesia. Data derived from the log activity of SCeLE Admin shows that the discussion forum within SCeLE, from the year 2011 to 2014, has not been utilized optimally by both students and lecturers. This is shown by a number of discussion forums and topics that were below 15 percent. The objective of this research is to investigate the factors that influence participation of online discussions within SCeLE MTI Universitas Indonesia (UI). Data is collected using questionnaires that are given to 150 students of MTI Study Program UI. Data processing used partial least square-SEM (PLS-SEM) with the aid of smartPLS3 software. Research finding shows that several factors that influence SCeLE online discussion generally are extrinsic motivation, habit, information quality, performance expectancy, social influence, system quality, and service quality. The factors that are very influential to behavioral intention are performance expectancy, habit, extrinsic motivation and social influence. Meanwhile, the factors that are very influential to user satisfaction are information quality, system quality and service quality.
\end{abstract}

Keywords: e-Learning, SCeLE, Participation, Online Discussion Forum, PLS-SEM

\begin{abstract}
Abstrak
Penggunaan $e$-Learning di Universitas Indonesia telah diatur oleh Surat Keputusan Rektor UI tentang Penyelenggaraan $e$-Learning di Universitas Indonesia. Dari data olahan log activity admin SCELE, diperoleh bahwa forum diskusi SCeLE sejak tahun 2011-2014 belum dimanfaatkan dengan maksimal baik oleh dosen maupun mahasiswa terlihat dari jumlah partisipasi dosen dan mahasiswa yang masih jauh dari harapan yaitu baik dari jumlah forum diskusi dan juga topik diskusi yang di-posting tidak lebih dari $15 \%$. Penelitan ini bertujuan untuk mencari faktor-faktor yang mempengaruhi partisipasi diskusi online pada SCeLE MTI UI. Pengumpulan data dilakukan dengan menggunakan kuesioner yang disebar kepada 150 responden mahasiswa MTI UI. Pengolahan data dilakukan menggunakan Partial Least Square-SEM (PLS-SEM) dengan bantuan software smartPLS 3. Hasil penelitian menunjukkan bahwa secara umum faktor-faktor yang mempengaruhi partisipasi diskusi online SCeLE adalah extrinsic motivation, habit, information quality, performance expectancy, social influence, system quality, dan service quality. Faktor yang sangat berpengaruh terhadap behavioral intention adalah performance expectancy, habit, extrinsic motivation, dan social influence. Sementara itu, faktor yang sangat berpengaruh terhadap user satisfaction adalah information quality, system quality dan service quality.
\end{abstract}

Kata Kunci: e-Learning,SCeLE, Partisipasi, Forum Diskusi Online, PLS-SEM

\section{Pendahuluan}

Penggunaan e-Learning di Universitas Indonesia telah diatur dengan dikeluarkannya Surat Keputusan Rektor UI Nomor 450/SK/R/UI/2008 tentang Penyelenggaraan $E$ Learning di Universitas Indonesia. Learning Management System yang digunakan di
Universitas Indonesia bernama student centered e-Learning environment (SCeLE). LMS dapat didefinisikan sebagai sistem yang mengatur bagaimana proses kegiatan belajar dilakukan dengan berbagai fasilitas yang dapat digunakan baik oleh siswa, pengajar, serta administrator sistem. SCeLE menggunakan Moodle sebagai core engine dengan beberapa fitur tambahan 
yang dikembangkan sendiri, seperti integrasi Graf Mata kuliah \& Assessment, Learning Object Manager, dan perpustakaan digital Library Automation and Digital Archive (LONTAR) [1].

Namun, sayangnya forum diskusi online di SCeLE MTI belum benar-benar dipergunakan dengan maksimal sebagai media komunikasi bagi dosen dan mahasiswa dilihat dari jumlah partisipasi dosen dan mahasiswa dalam forum diskusi online yang masih sangat rendah dalam kurun waktu empat tahun terakhir ini. Hal ini merupakan suatu kondisi yang tidak akan mendukung efektivitas penggunaan SCeLE. Salah satu kondisi yang harus dipenuhi untuk menerapkan student centered e-Learning (SCeL) secara efektif, yaitu pebelajar mampu memanfaatkan e-Learning sebagai sumber untuk mencari informasi dan pengetahuan, transfer knowledge, dan media komunikasi yang kolaboratif [2].

Dengan demikian sebenarnya akan ada manfaat yang hilang seperti yang telah disebutkan sebelumnya apabila diskusi online pada e-Learning (SCeLE) tidak digunakan secara maksimal. Sehingga, tujuan dari sistem pembelajaran student centered learning tidak dapat tercapai, yaitu salah satunya adalah pebelajar berpartisipasi dalam semua aspek pembelajaran dan pengambilan keputusan [2].

Berdasarkan data olahan activity log sistem SCeLE MTI UI pada tahun 2010/20112014/2015 yang diperoleh dari administrator SCeLE per tanggal 15 September 2014 ditemukan bahwa aktivitas dosen dan mahasiswa pada SCeLE MTI dapat dikatakan masih rendah. Terlebih lagi aktivitas mahasiswa pada forum diskusi online pada mata kuliah tertentu terbilang juga masih sangat rendah. Informasi tersebut dapat dilihat pada Gambar 1.

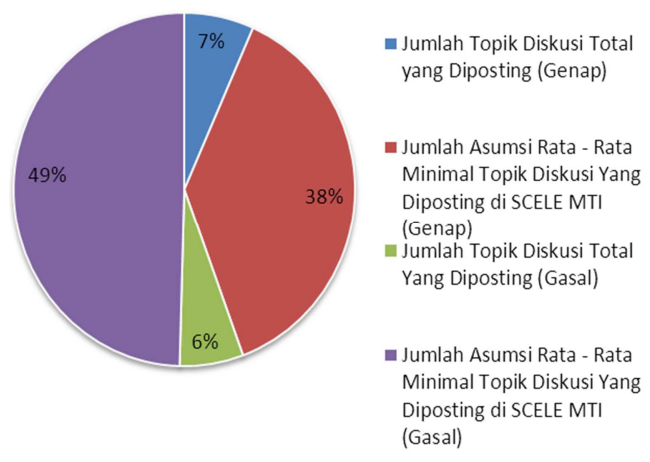

Gambar 1. Pie Chart Perbandingan Jumlah Topik Diskusi Total Online Dengan Jumlah Asumsi Rata - Rata Minimal Topik Diskusi Yang Diposting di SCeLE MTI Periode 2010/2011 - 2014/2015
Pada Gambar 1, terlihat bahwa persentase jumlah topik diskusi mata kuliah di SCeLE MTI pada tiap semester masih sangat kecil tidak lebih dari 10\% dan terjadi perbedaan (gap) yang sangat signifikan dengan prosentase jumlah asumsi rata - rata minimal topik diskusi mata kuliah di SCeLE MTI di tiap semesternya, yaitu $30 \%$. Angka ini juga menunjukkan bahwa tingkat partisipasi dosen dan mahasiswa dalam forum diskusi online di SCeLE MTI masih sangat rendah.

Berdasarkan fakta-fakta yang telah dipaparkan sebelumnya, ditemukan bahwa permasalahan nyata pada SCeLE MTI UI saat ini adalah masih rendahnya tingkat partisipasi dosen dan mahasiswa dalam forum diskusi online di SCeLE MTI. Isu inilah yang kemudian diangkat menjadi masalah penelitian. Berdasarkan identifikasi masalah yang muncul, maka dapat dirumuskan suatu pertanyaan penelitian yaitu faktor-faktor apa yang mempengaruhi partisipasi diskusi online dalam student centered e-Learning environment di MTI UI?

\section{Tinjauan Teoritis}

Student-centered e-Learning (SCeL) merupakan suatu paradigma pembelajaran yang merupakan penggabungan antara konsep student-centered dengan konsep e-Learning dalam mendukung proses pembelajaran. Penggabungan dua konsep ini diharapkan meningkatkan kualitas proses belajar mengajar. Menurut Motschnig-Pitrik dan Holzinger [2], terdapat beberapa kondisi yang harus dipenuhi untuk menerapkan SCeL secara efektif, yaitu sebagai berikut.

a) Materi-materi informasi yang dibutuhkan tersedia secara elektronis. Materi-materi tersebut adalah sumber informasi yang dibutuhkan seperti buku, jurnal, dan artikel.

b) Fasilitator yang mampu untuk menciptakan lingkungan pembelajaran yang konstruktif dan mempunyai kepribadian yang dibutuhkan dalam proses pembelajaran SceL.

c) Pembelajar yang mampu memanfaatkan media e-Learning sebagai alat untuk mencari informasi maupun proses komunikasi dan kolaborasi.

Menurut Motschnig-Pitrik dan Holzinger [2], terdapat beberapa manfaat yang dapat diperoleh dari SCeL, yaitu sebagai berikut.

a) Ketersediaan materi yang cukup banyak pilihannya dan sangat mudah. 
b) Internet dapat digunakan sebagai sumber pembelajaran.

c) Peserta didik menjadi lebih terbuka, kooperatif, konstruktif, dan bertanggung jawab terhadap dirinya.

d) Peserta didik dapat belajar dari beberapa contoh bukan hanya dari satu contoh.

e) Peserta didik yang pendiam dan kurang ekspresif dengan diskusi tatap muka cenderung lebih sering berpartisipasi dalam diskusi online karena memberikan banyak waktu untuk berpikir sebelum memberikan respon atau jawaban.

Salah satu fitur yang terdapat pada SCeLE adalah adanya forum diskusi sebagai media komunikasi antara dosen dengan mahasiswa dan antara mahasiswa dengan mahasiswa. Menurut Al-Shalchi [3] terdapat dua jenis diskusi online, yaitu diskusi asynchronousdan synchronous. Diskusi asynchronous merupakan diskusi yang dilakukan pada waktu yang tidak bersamaan dan dapat dilakukan kapan saja dan dimana saja.

Sementara itu, diskusi synchronous merupakan diskusi yang dilakukan dalam waktu dan tempat yang bersamaan. Forum diskusi yang terdapat pada SCeLE merupakan bentuk diskusi online secara asynchronous [3]. Ada beberapa manfaat yang diperoleh dengan diskusi online asynchronous, yaitu sebagai berikut :

a) Memberikan banyak waktu untuk berpikir terhadap suatu isu masalah yang dibahas sebelum meresponnya [3].

b) Dapat mengekspresikan dan mengelaborasikan pemikiran dan ide dari individu dengan lebih bebas dan mudah serta meningkatkan interaksi dengan yang lain [3].

c) Meningkatkan keterampilan bernalar (reasoning skill) dan mampu membangun pengetahuan [4].

d) Dapat dijadikan sebagai repositori ilmu pengetahuan [4].

e) Meningkatkan hasil pembelajaran (learning outcome) peserta didik [5].

f) Membangun kemampuan berpikir kritis (critical thinking) peserta didik terhadap topik diskusi [5].

Berdasarkan kontribusi penelitianpenelitian sebelumnya DeLone dan McLean [6] mereformulasikan model suksesnya dengan menambahkan faktor kualitas layanan (service quality) dan menghilangkan variabel individual impact dan organizational impact menjadi net benefit. Rekomendasi penambahan service quality sebagai salah satu dimensi IS success yang diterapkan khususnya dalam lingkungan $e$ commerce dimana pelayanan pelanggan menjadi hal yang sangat perlu diperhatikan.

Menurut DeLone dan McLean [6] disebutkan bahwa ukuran net benefit tergantung dari sudut pandang yang diambil, apakah dari perspektif individu atau organisasi. Pada tahun 2003, DeLone dan McLean memperbarui model kesuksesan sistem informasinya seperti yang terlihat pada Gambar 2.

UTAUT 2 merupakan pengembangan dari teori sebelumnya yaitu UTAUT yang dibuat oleh Venkatesh, Thong, dan $\mathrm{Xu}$ [7]. Model UTAUT 2 yang diajukan berfokus pada konsumen. Perbedaan model UTAUT 2 dengan UTAUT adalah dengan menambahkan tiga variabel baru yaitu hedonic motivation, price value, dan habit. Kelebihan dari model UTAUT 2 adalah adanya peningkatan secara substansial pada variabel behavioral intention sebesar 56$74 \%$ dan use behavior sebesar 40-52\% berdasarkan hasil penelitian yang dilakukan terhadap 1512 pelanggan mobile internet [7]. Dalam konteks penggunaan konsumen atas teknologi, pengaruh hedonic motivation, price value, dan habit adalah sangat kompleks. Pertama, dampak dari hedonic motivation atas behavioral intention dimoderatori oleh usia, jenis kelamin dan pengalaman konsumen. Kedua, pengaruh price value atas behavioral intention dimoderatori oleh usia dan jenis kelamin konsumen. Kemudian habit memiliki dampak-dampak secara langsung maupun termediasi atas penggunaan teknologi dan dampak-dampak tersebut dimoderatori oleh perbedaan-perbedaan individu konsumen.

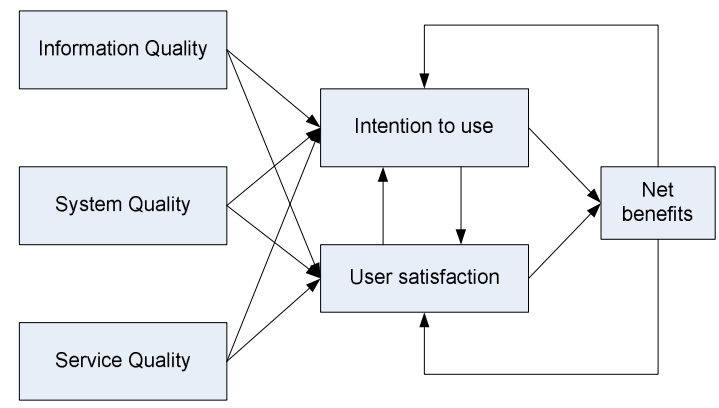

Gambar 2. Updated IS Success Model DeLone dan McLean 


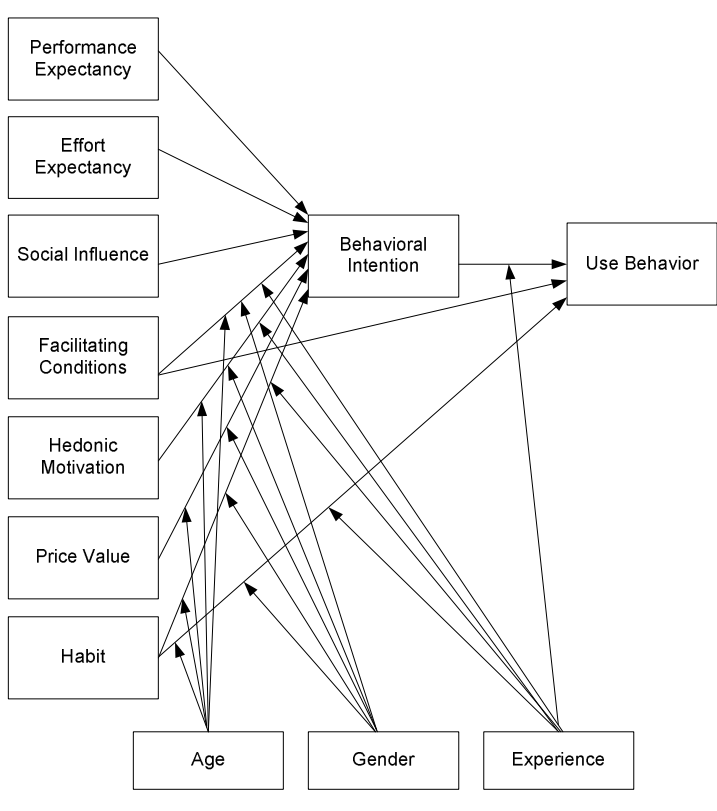

Gambar 3. Model UTAUT 2 Venkatesh, et al

PLS menggunakan algoritma iterasi yang terdiri dari seri OLS sehingga persoalan identifikasi model tidak menjadi masalah untuk model recursive (model yang mempunyai satu arah kausalitas) dan menghindarkan masalah untuk model yang bersifat non-recursive (model yang bersifat timbal balik atau resiprokal antar variabel) yang dapat diselesaikan oleh SEM berbasis kovarian. Sebagai alternatif analisis kovarian berbasis SEM, pendekatan variance based dengan PLS mengubah orientasi analisis dari menguji model kausalitas (model yang dikembangkan berdasarkan teori) ke model prediksi komponen.

Menurut Latan dan Ghozali [8] ada beberapa hal yang menjadi keuntungan dari analisis data menggunakan PLS, yaitu sebagai berikut :

a) Data sampel yang dipakai untuk analisis tidak harus terdistribusi normal secara multivarian.

b) Analisis dengan PLS dapat menggunakan sampel kecil.

c) Selain PLS dapat digunakan untuk melakukan konfirmasi akan suatu teori, ia juga dapat digunakan untuk menjelaskan ada atau tidaknya hubungan antar variabel laten.

d) PLS dapat menganalisis konstruk yang dibentuk dengan indikator reflektif dan formatif secara bersama-sama.

e) PLS mampu melakukan estimasi pada model yang besar dan kompleks yang memiliki ratusan variabel laten dan ribuan indikator.
Model PLS-SEM secara umum terdiri dari dua sub model yaitu model pengukuran atau disebut juga dengan outer model dan model struktural atau disebut juga dengan inner model. Model pengukuran menggambarkan bagaimana indikator merepresentasikan variabel laten untuk diukur. Sementara itu model struktural menunjukkan kekuatan estimasi antar variabel laten atau konstruk.

Menurut penelitian $\mathrm{Wu}$ dan Hwang [9], efektivitas $e$-Learning dipengaruhi oleh faktor kemudahan penggunaannya (ease of use), kekayaan interaksi media yang digunakan (media richness), dan motivasi eksternal (extrinsic motivation). Menurut penelitian Winoto [10], faktor yang mempengaruhi pengguna $e$-Learning khususnya dalam hal forum diskusi online dipengaruhi juga oleh jenis kelamin. Pada jenis kelamin pria, faktor yang berpengaruh adalah e-Learning motivation, social influence, dan facilitating condition, Sementara itu pada jenis kelamin wanita faktor yang berpengaruh adalah social influence, teacher's role, dan facilitating condition. Kedua peneliti tersebut mempunyai faktor yang sama dalam menentukan $e$-Learning yaitu motivasi baik motivasi internal maupun motivasi eksternal.

Menurut penelitian Santoso dan Hasibuan [1], faktor pemicu yang dapat mempengaruhi tingkat partisipasi diskusi online pada $e-$ learning adalah materi ajar berbasis multimedia, pemberian rewards dan keterlibatan dosen dalam diskusi. Menurut penelitian Te Yeh [11] instructor involvement in discussion dan reward nilai sangat mempengaruhi mahasiswa untuk terlibat aktif dalam diskusi online pada $e-$ Learning. Menurut penelitian Sahasrabudhe dan Kanungo [12], konten media text graphic sound dan text graphic talking-head sangat berpengaruh terhadap efektivitas e-learning yang dimoderatori oleh gaya belajar (learning style). Kedua peneliti tersebut Santoso dan Hasibuan [1] dan Sahasrabudhe dan Kanungo [12] mempunyai pendapat yang sama bahwa konten media sangat berpengaruh dalam penggunaan e-learning. Hal itu berbeda dengan pendapat Te Yeh [11] yang menyatakan bahwa peranan dosen dan adanya pemberian reward nilai juga menentukan pengaruh penggunaan $e-$ Learning.

Menurut penelitian Jingwei [13], gaya belajar (learning style) mahasiswa sangat mempengaruhi tingkat partisipasi dan interaksi dalam forum diskusi. Tipe gaya belajar yang sangat kuat pengaruhnya adalah diverger. Hal ini juga sejalan dengan penelitian yang dilakukan oleh Khan dan Iyer [14] serta 
Sahasrabudhe dan Kanungo [12] yang melibatkan gaya belajar mahasiswa dalam menentukan faktor penggunaan e-Learning. Yang menjadi perbedaaan dari ketiga peneliti tersebut adalah tipe gaya belajar yang digunakan. Jingwei [13] dan Sahasrabudhe dan Kanungo [12] menggunakan tipe gaya belajar yang diadopsi dari Kolb dan Kolb, Sementara itu Khan dan Iyer [14] menggunakan tipe gaya belajar yang diadopsi dari Riechmann dan Grasha [14]. Tidak ada alasan yang jelas dari ketiga peneliti tersebut yang menyebutkan mengapa mengadopsi tipe gaya belajar masingmasing serta apa relevansinya dengan penelitian mereka tersebut.

Dalam penelitian ini juga digunakan gaya belajar (learning style) sebagai variabel moderator dalam model penelitian. Akan tetapi peneliti mencoba mencari informasi untuk menentukan pemilihan gaya belajar yang akan digunakan dari suatu sumber referensi. Hal ini sangat penting karena peneliti mengusahakan agar tipe gaya belajar yang diadopsi dari suatu sumber nantinya akan mempunyai relevansi dengan disiplin akademik sebagai obyek penelitian yang akan dilakukan.

Peneliti mendefinisikan partisipasi diskusi online pada SCELE bergantung kepada niat pengguna (behavioral intention) dan kepuasan pengguna (user satisfaction). Niat pengguna (behavioral intention) merupakan faktor yang mendorong pengguna untuk berpartisipasi dalam forum diskusi online yang ditinjau dari aspek diri dan aspek sosial. Kepuasan pengguna (user satisfaction) merupakan faktor teknis dari sistem diskusi online. Jika niat pengguna dan kepuasan yang dirasakan oleh pengguna semakin besar, maka semakin besar pula partisipasi diskusi online pada SCeLE. Kerangka teoritis dari penelitian ini dapat dilihat pada Gambar 4.

Dari kerangka teoretis penelitian seperti pada Gambar 4, maka dapat dibuat hipotesis berdasarkan hubungan antar variabel laten. Hipotesis yang digunakan adalah menggunakan two-tailed dengan nilai level signifikansi 0,05.

\section{Metode penelitian}

Sampel penelitian ini berjumlah 150 orang mahasiswa MTI UI. Teknik pengambilan sampel dengan proportionate stratified sampling dimana masing-masing anggota populasi mempunyai peluang yang sama untuk dijadikan sampel yang memenuhi syarat. Pengumpulan data dilakukan dengan menyebarkan kuesioner. Data yang diperoleh dari kuesioner selanjutnya diolah dengan menggunakan software smartPLS 3. Evaluasi yang dilakukan terhadap model yang dibuat, yaitu evaluasi model PLS-SEM berupa evaluasi model pengukuran (outer model) dan evaluasi model struktural (inner model). Evaluasi model pengukuran (outer model) dilakukan untuk melihat validitas dan reliabilitas antara indikator-indikator variabel terhadap variabel laten eksogen. Sementara itu, evaluasi model struktural (inner model) dilakukan untuk menguji hipotesis dan melihat seberapa besar pengaruh model secara keseluruhan dapat memprediksi suatu penelitian (predictive relevance).

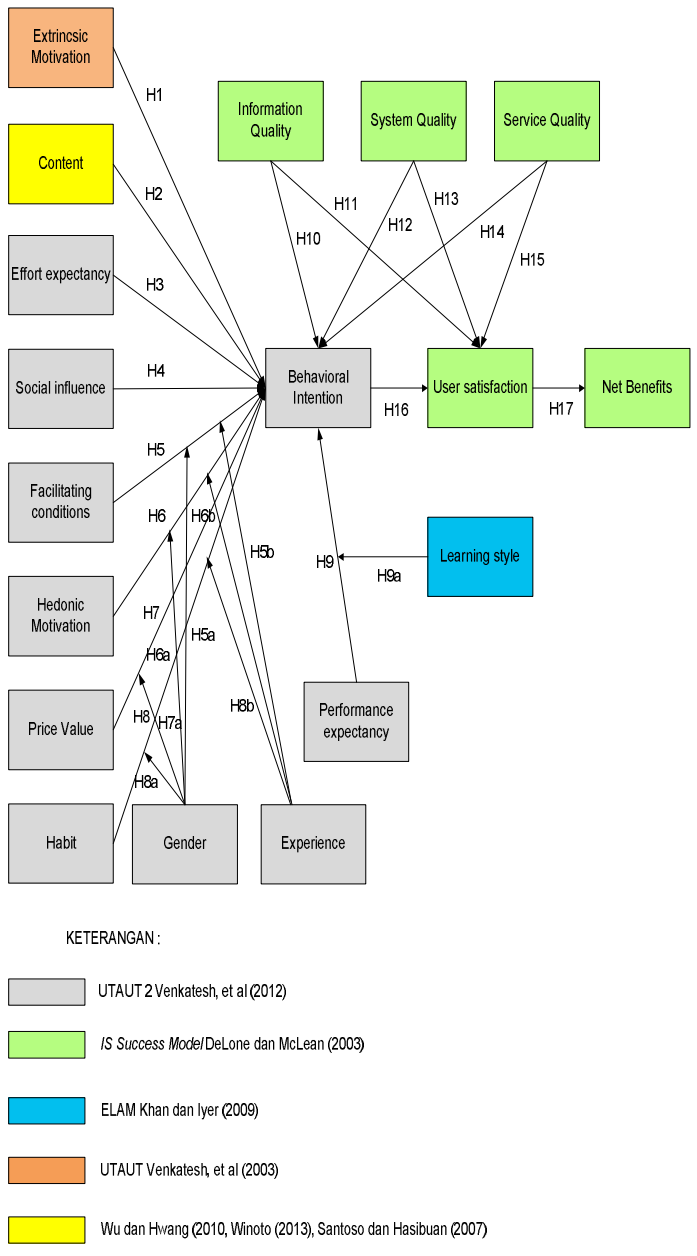

Gambar 4. Kerangka Teoretis Penelitian 


\section{Hasil dan Pembahasan}

Terdapat 6 model yang diuji berdasarkan variabel moderator-variabel moderator yang digunakan, yaitu model umum, model laki-laki, model perempuan, model gaya belajar visual dan sensing, serta model pengalaman 1-10 tahun dan lebih dari 10 tahun. Rangkuman hasil evaluasi model pengukuran (outer model) dan evaluasi model struktural (inner model) dari keseluruhan model dapat dilihat pada table-tabel berikut ini.

Pada TABEL I, terlihat bahwa untuk variabel gaya belajar (learning style) hanya evaluasi model dikarenakan jumlah responden yang memiliki kedua gaya belajar tersebut memenuhi syarat jumlah pengambilan sampel dengan metode PLS, yaitu minimal sampel harus berjumlah tiga puluh.

Pada TABEL II, terlihat bahwa nilai outer loadings untuk semua model memenuhi syarat, yaitu > 0,6 dan nilai AVE juga memenuhi syarat, yaitu $>0,5$. Dengan demikian tidak ada indikator-indikator kuesioner yang dibuang / dihapus. Begitu juga dengan nilai composite visual dan sensing yang digunakan untuk reliability dan cronbach alpha memenuhi syarat

untuk semua model, yaitu $>0,6$ sehingga dapat dikatakan bahwa seluruh item kuesioner adalah valid dan reliabel.

TABEL I

DEMOGRAFI RESPONDEN

\begin{tabular}{|c|c|c|c|}
\hline \multicolumn{2}{|c|}{ Klasifikasi/karakteristik } & Jumlah & Persentase \\
\hline \multirow{3}{*}{$\begin{array}{l}\text { Jenis Kelamin } \\
\text { (gender) } \\
\text { Total }\end{array}$} & Laki-Laki & 80 & 53.33 \\
\hline & Perempuan & 70 & 46.67 \\
\hline & & 150 & 100 \\
\hline \multirow{3}{*}{$\begin{array}{l}\text { Pengalaman } \\
\text { (experience) } \\
\text { Total }\end{array}$} & 1-10 tahun & 85 & 56.67 \\
\hline & $>10$ tahun & 65 & 43.33 \\
\hline & & 150 & 100 \\
\hline \multirow{9}{*}{$\begin{array}{l}\text { Gaya belajar } \\
\text { (learning } \\
\text { style) }\end{array}$} & Visual (VIS) & 75 & 50.00 \\
\hline & $\begin{array}{l}\text { Sensing } \\
\text { (SEN) }\end{array}$ & 50 & 33.33 \\
\hline & $\begin{array}{l}\text { Global } \\
\text { (GLO) }\end{array}$ & 10 & 6.67 \\
\hline & $\begin{array}{l}\text { Sequential } \\
\text { (SEQ) }\end{array}$ & 6 & 4.00 \\
\hline & $\begin{array}{l}\text { Active } \\
\text { (ACT) }\end{array}$ & 4 & 2.67 \\
\hline & $\begin{array}{l}\text { Reflective } \\
\text { (REF) }\end{array}$ & 2 & 1.33 \\
\hline & $\begin{array}{l}\text { Verbal } \\
\text { (VRB) }\end{array}$ & 2 & 1.33 \\
\hline & $\begin{array}{l}\text { Intuitive } \\
\text { (INT) }\end{array}$ & 1 & 0.67 \\
\hline & & 150 & 100 \\
\hline
\end{tabular}

TABEL II

RangKuman Hasil Evaluasi Model Pengukuran (OUTER MOdel)

\begin{tabular}{lccccc}
\hline \multicolumn{1}{c}{ Model Analisis } & Outer Loading & AVE & Akar AVE & Composite Reliability & Cronbach Alpha \\
\hline Umum & $0.81-0.97$ & $0.73-0.94$ & $0.85-0.97$ & $0.93-0.98$ & $0.90-0.98$ \\
Laki-Laki & $0.78-1.00$ & $0.66-0.99$ & $0.81-0.99$ & $0.91-1.00$ & $0.87-1.00$ \\
Perempuan & $0.79-0.95$ & $0.71-0.88$ & $0.84-0.94$ & $0.92-0.97$ & $0.89-0.96$ \\
Exp. 1-10 years & $0.80-0.97$ & $0.75-0.94$ & $0.87-0.97$ & $0.93-0.98$ & $0.90-0.98$ \\
Exp.> 10 years & $0.78-0.98$ & $0.69-0.94$ & $0.83-0.97$ & $0.92-0.99$ & $0.89-0.98$ \\
L.Style (VIS) & $0.78-0.98$ & $0.75-0.95$ & $0.87-0.98$ & $0.94-0.99$ & $0.91-0.98$ \\
L.Style (SEN) & $0.83-0.99$ & $0.73-0.97$ & $0.85-0.98$ & $0.93-0.99$ & $0.91-0.99$ \\
\hline
\end{tabular}

Pada TABEL III terlihat bahwa untuk semua model nilai Q-square memenuhi syarat semuanya, yaitu mendekati satu $\left(Q^{2}>0\right)$, itu artinya bahwa model penelitian yang dibangun merupakan model prediksi yang sangat baik.

TABEL III

RANGKUMAN HASIL EVALUASI MODEL STRUKTURAL (INNER

\begin{tabular}{lcc}
\multicolumn{3}{c}{ MODEL) } \\
\hline \multicolumn{1}{c}{ Model Analisis } & $R$ Square & $Q$ Square \\
\hline Umum & $0.43-0.74$ & 0.93 \\
Laki-Laki & $0.11-0.75$ & 0.85 \\
Perempuan & $0.17-0.85$ & 0.97 \\
Exp. 1-10 years & $0.31-0.80$ & 0.92 \\
Exp.> 10 years & $0.60-0.78$ & 0.97 \\
L.Style (VIS) & $0.35-0.73$ & 0.92 \\
L.Style (SEN) & $0.50-0.80$ & 0.96 \\
\hline
\end{tabular}

Pada TABEL IV dan TABEL V ada beberapa hipotesis yang diterima untuk setiap model, hipotesis diterima apabila nilai $\mathrm{T}$ statistik yang diperoleh > 1,96 [8]. Hipotesis yang diterima tersebut menandakan adanya faktor-faktor yang mempengaruhi partisipasi diskusi online baik dilihat dari sisi niat pengguna (behavioral intention) maupun kepuasan pengguna (user satisfaction).

Berdasarkan hasil uji hipotesis pada masing-masing model tersebut, didapati bahwa performance expectancy merupakan faktor yang hampir sering muncul dalam setiap model sebagai faktor yang sangat mempengaruhi niat pengguna (behavioral intention) untuk berpartisipasi dalam diskusi online di SCeLE. Faktor kedua diikuti oleh habit yang juga turut mempengaruhi niat pengguna (behavioral intention) untuk berpartisipasi dalam diskusi online di SCeLE. Faktor ketiga dan keempat masing-masing diikuti oleh extrinsic motivation dan social influence yang juga turut mempengaruhi niat pengguna (behavioral intention) untuk berpartisipasi dalam diskusi online di SCeLE. 
TABEL IV

RANGKUMAN HASIL UJI HIPOTESIS YANG DITERIMA

\begin{tabular}{|c|c|c|}
\hline Model Analisis & T-Statistics & Jalur \\
\hline \multirow{9}{*}{ Umum } & 2.13 & BI -> US \\
\hline & 2.11 & EM -> BI \\
\hline & 2.48 & H -> BI \\
\hline & 2.16 & IQ -> US \\
\hline & 3.91 & $\mathrm{PE}->\mathrm{BI}$ \\
\hline & 1.99 & SI -> BI \\
\hline & 4.43 & SQ -> US \\
\hline & 5.90 & SRV $\rightarrow$ US \\
\hline & 3.22 & $\mathrm{H}$-> BI \\
\hline \multirow[t]{6}{*}{ Laki - Laki } & 3.10 & IQ -> BI \\
\hline & 3.75 & IQ -> US \\
\hline & 3.16 & $\mathrm{PE}->\mathrm{BI}$ \\
\hline & 3.49 & SQ -> US \\
\hline & 4.35 & SRV $\rightarrow$ US \\
\hline & 5.73 & US -> NB \\
\hline \multirow[t]{7}{*}{ Perempuan } & 3.41 & $\mathrm{BI}->\mathrm{US}$ \\
\hline & 2.59 & $\mathrm{C} \rightarrow \mathrm{BI}$ \\
\hline & 3.22 & $\mathrm{H}->\mathrm{BI}$ \\
\hline & 2.07 & $\mathrm{IQ}->\mathrm{BI}$ \\
\hline & 2.73 & SQ -> US \\
\hline & 3.05 & SRV $\rightarrow$ US \\
\hline & 3.76 & US -> NB \\
\hline Gaya Belajar & 2.38 & BI $->$ US \\
\hline \multirow[t]{4}{*}{ Visual } & 3.80 & $\mathrm{PE}->\mathrm{BI}$ \\
\hline & 2.27 & SQ -> US \\
\hline & 8.80 & SRV $\rightarrow$ US \\
\hline & 8.64 & US -> NB \\
\hline
\end{tabular}

TABEL V

RANGKUMAN HASIL UJI HIPOTESIS YANG DITERIMA

\begin{tabular}{|c|c|c|}
\hline \multicolumn{3}{|c|}{ (LANJUTAN) } \\
\hline Model Analisis & T-Statistics & Jalur \\
\hline Gaya Belajar & 1.98 & $\mathrm{H}->\mathrm{BI}$ \\
\hline Sensing & 2.00 & $\mathrm{SI} \rightarrow \mathrm{BI}$ \\
\hline & 2.73 & SQ -> US \\
\hline & 3.82 & SRV $\rightarrow$ US \\
\hline & 9.58 & US $->$ NB \\
\hline Pengalaman 1-10 & 2.64 & $\mathrm{EM}->\mathrm{BI}$ \\
\hline Tahun & 3.24 & $\mathrm{H}->\mathrm{BI}$ \\
\hline & 2.16 & IQ -> US \\
\hline & 3.40 & $\mathrm{PE}->\mathrm{BI}$ \\
\hline & 2.12 & SQ -> US \\
\hline & 4.75 & SRV $->$ US \\
\hline & 8.04 & US -> NB \\
\hline Pengalaman $>10$ & 2.14 & $\mathrm{HM}->\mathrm{BI}$ \\
\hline Tahun & 3.06 & $\mathrm{PE}->\mathrm{BI}$ \\
\hline & 4.67 & SQ -> US \\
\hline & 3.37 & SRV -> US \\
\hline & 17.04 & US -> NB \\
\hline
\end{tabular}

Dengan demikian ada 4 faktor yang cukup kuat berpengaruh terhadap partisipasi diskusi online di SCeLE ditinjau dari sisi niat pengguna (behavioral intention), yaitu performance expectancy, habit, extrinsic motivation, dan social influence. Keempat faktor ini juga merupakan faktor yang mempengaruhi niat pengguna (behavioral intention) untuk berpartisipasi dalam diskusi online di SCeLE secara umum.

Strategi yang dapat dilakukan untuk meningkatkan partisipasi diskusi online di
SCeLE menurut pendapat peneliti berdasarkan pada keempat faktor tersebut adalah dosen menjadikan forum diskusi sebagai media komunikasi satu-satunya kepada mahasiswa dalam kaitannya dengan perkuliahan di luar kelas. Dosen dapat memberikan informasi perubahan jadwal kuliah di forum diskusi, informasi waktu ujian, batas waktu (deadline) pengumpulan tugas kuliah melalui forum diskusi, atau sekedar sharing informasi (hot topics) seputar materi perkuliahan.

Selain itu yang tak kalah pentingnya adalah dosen sering memberikan pertanyaanpertanyaan melalui forum diskusi yang dijawab oleh mahasiswa di forum diskusi tersebut dan dosen memberikan penilaian dan evaluasi terhadap jawaban atau pendapat yang disampaikan oleh mahasiswa tersebut. Jawaban atau pendapat yang disampaikan oleh mahasiswa tersebut diberi nilai tersendiri oleh dosen sebagai reward nilai untuk menambah poin yang nantinya diakumulasikan pada nilai akhir mahasiswa dan bila perlu nilai tersebut dapat dipublikasikan di forum diskusi.

Seorang mahasiswa juga dapat berkontribusi untuk memberikan pertanyaanpertanyaan kepada dosen, menanggapi pertanyaan-pertanyaan dari mahasiswa lain, atau sekedar sharing informasi (hot topics) terkait materi perkuliahan dimana nantinya dosen juga dapat memberikan reward nilai sesuai dengan kriteria bobot tertentu atas pertanyaan dan sharing informasi yang diberikan oleh mahasiswa tersebut di forum diskusi.

Selain kedua hal, mungkin perlu juga agar dosen memberikan soal-soal ujian yang diambil dari pembahasan diskusi online di forum. Strategi tersebut diharapkan dapat memicu mahasiswa untuk aktif berpartisipasi dalam diskusi online di forum diskusi. Dengan demikian jika hal itu sudah menjadi komitmen dosen, mau tidak mau mahasiswa dan dosen setiap hari akan selalu membuka forum diskusi untuk update informasi di dalamnya. Sehingga hal tersebut akan menjadi suatu kebiasaan (habit) bagi para mahasiswa dan dosen.

Mahasiswa juga akan diuntungkan dengan aktif berpartisipasi dalam diskusi online, yaitu mereka dapat memperbaiki atau meningkatkan nilai mata kuliah dari reward nilai tersebut yang diakumulasikan pada nilai akhir. Kalau ada nilai ujian kuis, UTS, atau UAS yang jauh dari harapan tentunya akan sangat membantu sekali untuk kelulusan mata kuliah itu. Disinilah peran dosen sebagai fasilitator diskusi online di SCeLE untuk menumbuhkan kebiasaan (habit) mahasiswa dalam berpendapat dan berpikir kritis terhadap suatu permasalahan melalui 
forum serta saling berbagi informasi dan pengetahuan. Sehingga nantinya akan ada yang menjadi pusat pengaruh (center of influence) yang dapat mempengaruhi banyak mahasiswa untuk terlibat aktif berpartisipasi dalam diskusi online di SCeLE.

Dari sisi kepuasan pengguna (user satisfaction), pada setiap model yang diuji ada tiga faktor yang mempengaruhi partisipasi diskusi online, yaitu information quality, system quality, dan service quality. Strategi yang dapat dilakukan oleh pihak MTI terhadap ketiga faktor tersebut adalah dengan upgrading sistem SCeLE. Selain itu juga, meningkatkan kecepatan akses SCeLE serta menyediakan layanan online bagi pengguna SCeLE seperti help desk jika terjadi gangguan terhadap akses SCeLE atau password yang sudah lewat masa aktifnya (expired) tanpa harus datang ke kampus.

Saat ini aplikasi SCeLE masih merupakan sistem informasi yang berbasis web. Perlu diketahui bahwa saat ini jumlah pengguna internet mobile di Indonesia mencapai 200 juta jiwa hingga akhir tahun 2014 [15]. Pengguna internet mobile di Indonesia sampai november 2014 didominasi oleh platform Android seperti yang terlihat pada Gambar 5.

Dari Gambar 5 terlihat bahwa jumlah pengguna internet mobile yang terbanyak di Indonesia adalah platform Android (52,33\%). Hal ini tidak menutup kemungkinan bahwa sebagian besar dosen dan mahasiswa MTI UI juga adalah pengguna platform Android. Tentunya hal tersebut akan sangat menarik apabila pihak Fasilkom UI dapat mengimplementasikan aplikasi SCeLE yang berbasis mobile device dengan berbagai platform operating system (OS) terutama platform Android.

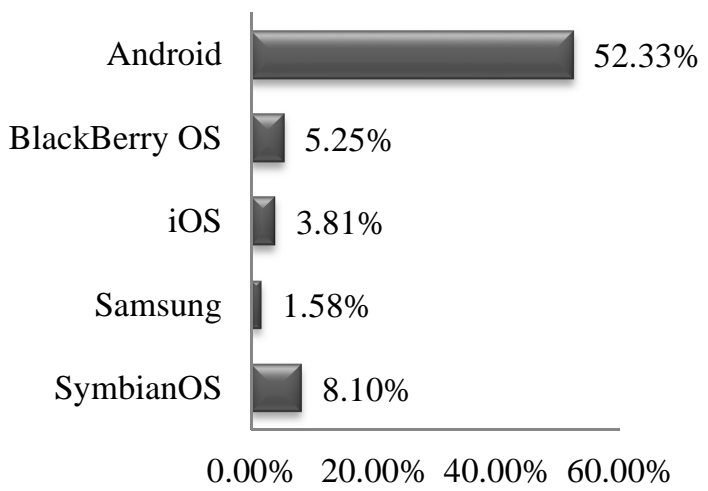

Gambar 5. Perbandingan Jumlah Pengguna Internet Mobile di Indonesia Dari Berbagai Platform OS Hingga November 2014. Sumber : http://gs.statcounter.com/\#mobile_os-IDmonthly-201311-201411-bar -Telah Diolah Kembali
Aplikasi tersebut dapat diunduh pada perangkat smartphone secara gratis. Sehingga nantinya diskusi online dapat dilakukan secara mobile dengan penambahan fitur push notification sebagai pemberitahu pesan jika ada update diskusi online di SCeLE seperti pada aplikasi messenger WhatsApp, WeChat, dan Line. Dengan demikian diskusi online di SCeLE akan lebih fleksibel dan praktis.

\section{Kesimpulan}

Penelitian ini dilakukan untuk menjawab pertanyaan penelitian yang telah dirumuskan oleh peneliti. Secara umum peneliti mendefinisikan partisipasi diskusi online pada SCeLE dilihat dari dua sisi yang mempengaruhi yaitu behavioral intention dan user satisfaction. Kesimpulan yang dapat diambil adalah sebagai berikut:

1. Pada model umum faktor-faktor yang mempengaruhi partisipasi diskusi online pada SCeLE adalah extrinsic motivation, habit, information quality, performance expectancy, social influence, system quality, dan service quality.

2. Pada model dengan jenis kelamin laki-laki faktor-faktor yang mempengaruhi partisipasi diskusi online pada SCeLE adalah information quality, performance expectancy, system quality, dan service quality.

3. Pada model dengan jenis kelamin perempuan faktor-faktor yang mempengaruhi partisipasi diskusi online pada SCeLE adalah content, habit, information quality, system quality, dan service quality.

4. Pada model dengan gaya belajar visual faktor-faktor yang mempengaruhi partisipasi diskusi online pada SCeLE adalah performance expectancy, system quality, dan service quality.

5. Pada model dengan gaya belajar sensing faktor-faktor yang mempengaruhi partisipasi diskusi online pada SCeLE adalah system quality, service quality, habit, dan social inluence.

6. Pada model dengan pengalaman 1-10 tahun faktor-faktor yang mempengaruhi partisipasi diskusi online pada SCeLE adalah system quality, service quality, habit, information quality, extrinsic motivation, dan performance expectancy.

7. Pada model dengan pengalaman $>10$ tahun faktor-faktor yang mempengaruhi partisipasi diskusi online pada SCeLE adalah system 
quality, service quality, hedonic motivation, dan performance expectancy.

8. Ada tiga faktor yang mempengaruhi partisipasi diskusi online di SCeLE ditinjau dari kepuasan pengguna (user satisfaction), yaitu information quality, system quality, dan service quality.

\section{Saran}

Berdasarkan temuan faktor-faktor yang berpengaruh pada model, beberapa rekomendasi yang dapat dipertimbangkan oleh pihak MTI UI dan dosen sebagai berikut :

a) Pihak MTI UI meningkatkan kualitas layanan SCeLE baik untuk dosen maupun mahasiswa dengan menyediakan help desk terkait penyelesaian masalah yang dilaporkan oleh dosen dan mahasiswa dalam penggunaan SCeLE.

b) Perlu di-upgrade mengenai fitur-fitur pada forum diskusi SCeLE agar lebih menarik lagi dengan berbasis multimedia untuk menarik minat dosen dan mahasiswa aktif berdikusi pada forum diskusi SCeLE.

c) Pihak Fasilkom UI dapat memfasilitasi diskusi online di SCeLE berbasis mobile application yang dapat diunduh secara gratis pada smartphone dalam berbagai platform sistem operasi terutama platform android dengan sistem push notification sehingga diskusi akan lebih fleksibel dan praktis.

d) Dosen tidak hanya sebagai silent reader tetapi dapat lebih proaktif dalam forum diskusi SCeLE untuk memberikan feedback dan topik-topik yang dapat menstimulasi mahasiswa untuk aktif berdiskusi di forum karena ada saja mahasiswa yang terkadang malu untuk bertanya/diskusi dengan dosen di kelas tetapi dapat aktif bertanya dan berdiskusi jika melalui forum diskusi.

e) Jika memungkinkan dosen dapat memberikan nilai tambah (reward) bagi mahasiswa yang aktif di forum diskusi dengan kriteria bobot penilaian yang dibuat sedemikian rupa untuk menarik minat mahasiswa.

f) Ada baiknya dosen dapat melakukan survei kelas untuk mengetahui secara umum tipe gaya belajar mahasiwa yang diajar di kelasnya sehingga dapat memberikan metode pengajaran yang sesuai dengan tipe gaya belajar mahasiswa tersebut.

Sedangkan saran untuk penelitian selanjutnya ialah:

a) Sampel penelitian dapat ditambah jumlahnya, yaitu dengan melibatkan responden yang berasal dari dosen Fasilkom UI.

b) Penelitian ini dapat dikembangkan dengan menggunakan metode campuran (mix method), yaitu kuantitatif dan kualitatif. Metode kualitatif dapat dilakukan dengan experimental / quasi-experimental.

c) Jika menggunakan metode kualitatif, dapat juga dianalisis untuk mencari pola diskusi online yang diinginkan oleh mahasiswa, seperti pola diskusi terbuka, semi terbuka, atau tertutup.

\section{Referensi}

[1] H. B. Santoso and Z. A. Hasibuan, "Pengaruh Faktor Pemicu Terhadap Tingkat Partisipasi Diskusi Dalam Student Centered e-Learning Environment," in SNATI, 2007.

[2] R. Motschnig-Pitrik and A. Holzinger, "Student-Centered Teaching Meets New Media : Concept and Case Study," Educational Technology \& Society, vol. 5, no. 4, 2002.

[3] O. Al-Shalchi, "The Effectiveness and Development of Online Discussions," Journal of Online Learning and Teaching, vol. 5, no. 1, 2009.

[4] L. H. Chen and H. C. Lin, "Integrating Kano's Model Into e-Learning Satisfaction," in The 2007 IEEE IEEM, 2007.

[5] R. A. Green, D. Farchione, D. L. Hughes, and S. P. Chan, "Participation in Asynchronous Online Discussion Forums Does Improve Student Learning of Gross Anatomy," Anatomical Sciences Education, pp. 71-76, 2014.

[6] W. H. Delone and E. R. McLean, "The Delone and McLean Model of Information System Success : A Ten-Year Update," Journal of Management Information System, 2003.

[7] V. Venkatesh, J. Y. Thong, and X. Xu, "Consumer Acceptance and Use of Information Technology : Extending The Unified Theory of Acceptance and Use of Technology," MIS Quarterly, vol. 36, no. 1, pp. 157-178, 2012.

[8] H. Latan and I. Ghozali, Partial Least Squares : Konsep, Teknik dan Aplikasi Menggunakan Program SmartPLS 2.0 M3. Semarang: BP Undip, 2012.

[9] W. Wu and L. Y. Hwang, "The Effectiveness of e-Learning for Blended Courses in College : A Multi-Level Empirical Study," International Journal of 
Electronic Business Management, vol. 8, no. 4, pp. 312-322, 2010.

[10] A. T. Winoto, "Analisis Faktor - Faktor Yang Mempengaruhi Mahasiswa Dalam Menggunakan Sistem Diskusi Online SceLe di Program Magister Teknologi Informasi Universitas Indonesia," Universitas Indonesia, 2013.

[11] Y. H. Te, "The Use of Instructor's Feedback and Grading in Enhacing Students'Participation in Asynchronous Online Discussion," in The Fifth IEEE International Conference on Advanced Learning Technologies (ICALT'05), 2005.

[12] V. Sahasrabudhe and S. Kanungo, "Appropriate Media Choice For eLearning Effectiveness : Role of Learning
Domain and Learning Style," Computers \& Education, vol. 76, pp. 237-249, 2014.

[13] Z. Jingwei, "Empirical Study on Online Interaction Based on Learning Style Differences," in The 6th INternational Conference on Computer Science \& Education (ICCSE 2011), Singapore, 2011, pp. 1023-1026.

[14] F. U. Khan and S. Iyer, "A Model for Acceptance and Use of e-Learning by Teachers and Students," in 4th International Conference on e-Learning, Toronto, 2009, pp. 475-485.

[15] A. Elfirasy. (2014, ) Jumlah Pengguna Internet Mobile di Indonesia. [Online]. http://www.sb1 msumbar.blogspot.com/20 14/12/jumlah-pengguna-internet-mobiledi.html

\section{Lampiran}

\begin{tabular}{|c|c|c|}
\hline \multicolumn{3}{|c|}{ LAMPIRAN TABEL I } \\
\hline Konstruksi & Item (Indikator) & Sumber \\
\hline \multirow[t]{5}{*}{$\begin{array}{l}\text { Performance expectancy } \\
\text { (PE) }\end{array}$} & $\begin{array}{l}\text { PE1 = forum diskusi online SCELE membantu mendapatkan nilai } \\
\text { yang lebih baik }\end{array}$ & $\begin{array}{l}\text { Venkatesh, et al (2012), Khan } \\
\text { dan Iyer (2009) }\end{array}$ \\
\hline & $\begin{array}{l}\text { PE2 = forum diskusi online SCELE membantu mengerjakan tugas } \\
\text { kuliah lebih cepat dan efektif }\end{array}$ & $\begin{array}{l}\text { Venkatesh, et al (2012), Khan } \\
\text { dan Iyer (2009) }\end{array}$ \\
\hline & $\begin{array}{l}\text { PE3 = forum diskusi online SCELE membantu mendapatkan } \\
\text { jawaban atas pertanyaan diskusi dalam waktu yang relatif cepat }\end{array}$ & Khan dan Iyer (2009) \\
\hline & $\begin{array}{l}\text { PE4 = forum diskusi online SCELE memberikan fleksibilitas } \\
\text { diskusi kapan saja dan dimana saja }\end{array}$ & Khan dan Iyer (2009) \\
\hline & $\begin{array}{l}\text { PE5 = forum diskusi online SCELE membantu interaksi dengan } \\
\text { mahasiswa lain dan dosen dalam menyelesaikan tugas dan soal } \\
\text { latihan }\end{array}$ & Khan dan Iyer (2009) \\
\hline \multirow[t]{4}{*}{ Effort Expectancy (EE) } & EE1= Kemudahan menggunakan fitur diskusi online SCELE & $\begin{array}{l}\text { Venkatesh, et al (2012), Khan } \\
\text { dan Iyer (2009) }\end{array}$ \\
\hline & $\begin{array}{l}\text { EE2= Membantu untuk menjadi lebih berkompeten dalam } \\
\text { menggunakan forum dikusi online SCELE }\end{array}$ & $\begin{array}{l}\text { Venkatesh, et al (2012), Khan } \\
\text { dan Iyer (2009) }\end{array}$ \\
\hline & $\begin{array}{l}\text { EE3= Mempunyai keahlian yang cukup untuk menggunakan fitur } \\
\text { diskusi online SCELE }\end{array}$ & $\begin{array}{l}\text { Venkatesh, et al (2012), Khan } \\
\text { dan Iyer (2009) }\end{array}$ \\
\hline & $\begin{array}{l}\text { EE4= Mempunyai cukup waktu untuk berdiskusi di forum diskusi } \\
\text { SCELE }\end{array}$ & Dikembangkan oleh peneliti \\
\hline \multicolumn{3}{|c|}{ LAMPIRAN TABEL II } \\
\hline Konstruksi & Item (Indikator) & Sumber \\
\hline \multirow[t]{4}{*}{ Social Influence (SI) } & $\begin{array}{l}\text { SI1= orang yang berpengaruh (dosen, teman kuliah, pimpinan } \\
\text { fakultas) menyarankan agar berperan aktif menggunakan forum } \\
\text { diskusi online SCELE }\end{array}$ & $\begin{array}{l}\text { Venkatesh, et al (2012), Khan } \\
\text { dan Iyer (2009) }\end{array}$ \\
\hline & $\begin{array}{l}\text { SI2 = mahasiswa yang aktif di forum diskusi online SCELE terlihat } \\
\text { lebih prestisius daripada yang tidak aktif }\end{array}$ & $\begin{array}{l}\text { Venkatesh, et al (2003), Khan } \\
\text { dan Iyer (2009) }\end{array}$ \\
\hline & $\begin{array}{l}\text { SI3 = mahasiswa yang aktif di forum diskusi online SCELE } \\
\text { dianggap pintar (smart) }\end{array}$ & $\begin{array}{l}\text { Venkatesh, et al (2003), Khan } \\
\text { dan Iyer (2009) }\end{array}$ \\
\hline & $\begin{array}{l}\text { SI } 4=\text { merasa tertinggal dengan yang lain (kurang update ) jika } \\
\text { tidak aktif di forum diskusi SCELE }\end{array}$ & Dikembangkan oleh peneliti \\
\hline \multirow[t]{4}{*}{$\begin{array}{l}\text { Facilitating } \\
\text { (FC) }\end{array}$} & $\begin{array}{l}\text { FC1=kampus sudah menyediakan fasilitas yang memadai untuk } \\
\text { mengakses SCELE }\end{array}$ & $\begin{array}{l}\text { Venkatesh, et al (2012), Khan } \\
\text { dan Iyer (2009) }\end{array}$ \\
\hline & $\begin{array}{l}\text { FC2 = bantuan teknis yang tersedia jika diperlukan saat mengakses } \\
\text { SCELE }\end{array}$ & $\begin{array}{l}\text { Venkatesh, et al (2012), Khan } \\
\text { dan Iyer (2009) }\end{array}$ \\
\hline & $\begin{array}{l}\text { FC3=pimpinan fakultas/program studi aktif di forum diskusi online } \\
\text { SCELE }\end{array}$ & Khan dan Iyer (2009) \\
\hline & $\begin{array}{l}\text { FC4=pimpinan fakultas/program studi mendukung mahasiswa } \\
\text { untuk aktif menggunakan forum diskusi online SCELE }\end{array}$ & Khan dan Iyer (2009) \\
\hline
\end{tabular}


Meyer E.Sihotang, et al., Investigasi Faktor-Faktor yang Mempengaruhi Partisipasi Diskusi Online 11

LAMPIRAN TABEL III

\begin{tabular}{|c|c|c|}
\hline Konstruksi & Item (Indikator) & Sumber \\
\hline \multirow[t]{5}{*}{ Price Value (PV) } & PV1=biaya akses internet saat ini terjangkau dan wajar & Venkatesh, et al (2012) \\
\hline & $\begin{array}{l}\text { PV2=berdiskusi melalui forum diskusi online SCELE banyak } \\
\text { memberi keuntungan }\end{array}$ & Venkatesh, et al (2012) \\
\hline & PV3=diskusi online SCELE tidak terbatas oleh letak geografis & Dikembangkan oleh peneliti \\
\hline & PV4=diskusi online SCELE tidak terbatas oleh waktu & Dikembangkan oleh peneliti \\
\hline & PV5=diskusi online SCELE sangat praktis dan ekonomis & Dikembangkan oleh peneliti \\
\hline \multirow[t]{4}{*}{ Habit $(\mathrm{H})$} & $\mathrm{H} 1=$ menggunakan SCELE menjadi kebiasaan rutin setiap hari & Venkatesh, et al (2012) \\
\hline & $\mathrm{H} 2=$ tidak bisa belajar tanpa bantuan internet & Venkatesh, et al (2012) \\
\hline & $\begin{array}{l}\mathrm{H} 3=\text { sudah lama bergabung dan aktif pada komunitas online } \\
\text { (contoh : kaskus, sosial media, milis, dll) }\end{array}$ & Dikembangkan oleh peneliti \\
\hline & $\begin{array}{l}\text { H4=Lebih nyaman berdiskusi secara online daripada offline (tatap } \\
\text { muka) }\end{array}$ & Dikembangkan oleh peneliti \\
\hline \multirow[t]{3}{*}{ Information Quality (IQ) } & $\begin{array}{l}\text { IQ1 = Informasi yang disajikan dalam forum diskusi SCELE } \\
\text { sangat relevan dengan keinginan mahasiswa }\end{array}$ & Delone dan McLean (2003) \\
\hline & $\begin{array}{l}\text { IQ2 = Bahasa yang digunakan dalam diskusi di forum diskusi } \\
\text { SCELE mudah dipahami oleh mahasiswa }\end{array}$ & Delone dan McLean (2003) \\
\hline & LAMPIRAN TABEL IV & \\
\hline \multirow[t]{4}{*}{ Konstruksi } & Item (Indikator) & Sumber \\
\hline & $\begin{array}{l}\text { IQ3 = Informasi yang disajikan sangat akurat dengan teori mata } \\
\text { kuliah }\end{array}$ & Delone dan McLean (1992) \\
\hline & $\begin{array}{l}\text { IQ4 = Topik diskusi yang dibahas sangat bermanfaat dan } \\
\text { informatif }\end{array}$ & Delone dan McLean (1992) \\
\hline & $\begin{array}{l}\text { IQ5 = Feedback (umpan balik) yang diberikan dalam forum } \\
\text { diskusi SCELE tidak menjatuhkan (menyudutkan) }\end{array}$ & Dikembangkan oleh peneliti \\
\hline \multirow[t]{4}{*}{ System Quality (SQ) } & $\begin{array}{l}\text { SQ1 = SCELE dapat merespon proses dan memberikan data } \\
\text { informasi dengan cepat }\end{array}$ & Delone dan McLean (2003) \\
\hline & SQ2 = Web SCELE dapat diakses di berbagai sistem operasi & Delone dan McLean (2003) \\
\hline & $\begin{array}{l}\text { SQ3 = Diskusi dalam forum diskusi SCELE dapat dilakukan } \\
\text { dengan secara mobile }\end{array}$ & Delone dan McLean (1992) \\
\hline & $\begin{array}{l}\text { SQ4 = SCELE dapat diakses di berbagai aplikasi penjelajah } \\
\text { (browser) tanpa ada masalah }\end{array}$ & Dikembangkan oleh peneliti \\
\hline \multirow[t]{4}{*}{ Service Quality (SRV) } & $\begin{array}{l}\text { SRV1 = Staf TI di kampus cepat tanggap jika koneksi internet } \\
\text { terganggu }\end{array}$ & Delone dan McLean (2003) \\
\hline & $\begin{array}{l}\text { SRV2 = Staf TI di kampus sangat handal dan cepat menangani } \\
\text { gangguan akses SCELE }\end{array}$ & Parasuraman, et al (1985) \\
\hline & SRV3 = Tersedia helpdesk untuk melapor gangguan akses SCELE & Parasuraman, et al (1985) \\
\hline & $\begin{array}{l}\text { SRV4 = Kepercayaan terhadap kinerja dan layanan staf TI di } \\
\text { kampus }\end{array}$ & Delone dan McLean (2003) \\
\hline \multicolumn{3}{|c|}{ LAMPIRAN TABEL V } \\
\hline Konstruksi & Item (Indikator) & Sumber \\
\hline \multirow[t]{5}{*}{ Contents $(\mathrm{C})$} & $\begin{array}{l}\mathrm{C} 1 \text { = lebih suka dengan konten diskusi online SCELE berbasis } \\
\text { multimedia }\end{array}$ & $\begin{array}{l}\text { Sahasrabudhe dan Kanungo } \\
(2014) \text {, Santoso dan } \\
\text { Hasibuan (2007) }\end{array}$ \\
\hline & $\begin{array}{l}\mathrm{C} 2 \text { Konten diskusi online yang ada di SCELE sudah cukup } \\
\text { memadai }\end{array}$ & Chen dan Lin (2007) \\
\hline & $\begin{array}{l}\mathrm{C} 3=\text { Mahasiswa dapat mengerti bahasa konten yang diberikan } \\
\text { dalam forum diskusi online SCELE }\end{array}$ & Winoto (2013) \\
\hline & $\begin{array}{l}\mathrm{C} 4 \text { = Konten yang diberikan dalam forum diskusi online SCELE } \\
\text { up to date }\end{array}$ & Chen dan Lin (2007) \\
\hline & $\begin{array}{l}\text { C5 = Konten diskusi online SCELE sudah sesuai dengan } \\
\text { kebutuhan mahasiswa }\end{array}$ & Chen dan Lin (2007) \\
\hline \multirow[t]{4}{*}{ Behavioral Intention (BI) } & $\begin{array}{l}\text { BI1 = Berniat untuk terus menggunakan forum diskusi online } \\
\text { SCELE selama kuliah }\end{array}$ & Venkatesh, et al (2012) \\
\hline & $\begin{array}{l}\text { BI2 = Berniat menggunakan forum diskusi online SCELE untuk } \\
\text { mencari dan berbagi pengetahuan (knowledge sharing) }\end{array}$ & Dikembangkan oleh peneliti \\
\hline & $\begin{array}{l}\text { BI3 = Berniat merekomendasikan forum diskusi SCELE kepada } \\
\text { mahasiswa lain }\end{array}$ & Winoto (2013) \\
\hline & $\begin{array}{l}\text { BI4 = Berniat menggunakan forum diskusi SCELE dalam } \\
\text { membantu pembelajaran }\end{array}$ & Venkatesh, et al (2012) \\
\hline
\end{tabular}


12 Journal of Information Systems, Volume 11, Issue 1, April 2015

\begin{tabular}{|c|c|c|}
\hline \multicolumn{3}{|c|}{ LAMPIRAN TABEL VI } \\
\hline Konstruksi & Item (Indikator) & Sumber \\
\hline \multirow{6}{*}{ User Satisfaction (US) } & US1=mahasiswa puas terhadap sistem $e$ - learning SCELE & Delone dan McLean (1992) \\
\hline & $\begin{array}{l}\text { US2 }=\text { forum diskusi online SCELE sesuai dengan gaya belajar } \\
\text { (learning style) }\end{array}$ & Dikembangkan oleh peneliti \\
\hline & $\begin{array}{l}\text { US3=mahasiswa puas karena forum diskusi online SCELE sesuai } \\
\text { dengan media komunikasi yang diinginkan }\end{array}$ & Dikembangkan oleh peneliti \\
\hline & $\begin{array}{l}\text { US4 = mahasiswa puas dengan forum diskusi SCELE karena } \\
\text { membuat lebih mudah memahami materi dan tugas kuliah }\end{array}$ & Dikembangkan oleh peneliti \\
\hline & US5 = mahasiswa puas karena opini dalam forum diskusi online & Dikembangkan oleh peneliti \\
\hline & $\begin{array}{l}\text { SCELE mendapat tanggapan yang positif dan cepat dari dosen dan } \\
\text { mahasiswa lain }\end{array}$ & \\
\hline \multirow[t]{4}{*}{ Net Benefits (NB) } & $\begin{array}{l}\text { NB1 = Mempunyai topik - topik diskusi untuk didiskusikan di } \\
\text { forum diskusi online SCELE }\end{array}$ & Torkzadeh dan Doll (1999) \\
\hline & $\begin{array}{l}\text { NB2 = Forum diskusi SCELE membantu meningkatkan kualitas } \\
\text { belajar }\end{array}$ & Davis (1989) \\
\hline & $\begin{array}{l}\text { NB3 = Menggunakan forum diskusi SCELE menghemat biaya } \\
\text { dibandingkan dengan diskusi via telepon/sms }\end{array}$ & Delone dan McLean (2003) \\
\hline & \multicolumn{2}{|l|}{ LAMPIRAN TABEL VII } \\
\hline Konstruksi & Item (Indikator) & Sumber \\
\hline \multirow{8}{*}{ Extrinsic Motivation (EM) } & $\begin{array}{l}\text { NB4 = Forum diskusi SCELE membantu meningkatkan nilai mata } \\
\text { kuliah }\end{array}$ & Davis (1989) \\
\hline & $\begin{array}{l}\text { NB5 = Forum diskusi SCELE membantu menyelesaikan tugas } \\
\text { kuliah lebih cepat }\end{array}$ & Davis (1989) \\
\hline & $\begin{array}{l}\text { NB6 = Forum diskusi SCELE membantu mendapatkan } \\
\text { pengetahuan dan pengalaman baru }\end{array}$ & Dikembangkan oleh peneliti \\
\hline & $\begin{array}{l}\text { EM1=Aktif menggunakan forum diskusi SCELE apabila ada } \\
\text { reward nilai mata kuliah }\end{array}$ & Ryan dan Deci (2000) \\
\hline & $\begin{array}{l}\text { EM2=Aktif menggunakan forum diskusi SCELE jika dosen yang } \\
\text { bersangkutan juga aktif di forum diskusi SCELE }\end{array}$ & $\begin{array}{l}\text { Venkatesh, et al (2003), Ryan } \\
\text { dan Deci (2000) }\end{array}$ \\
\hline & $\begin{array}{l}\text { EM3 = Perlu adanya sanksi dari dosen jika tidak aktif di forum } \\
\text { diskusi online SCELE }\end{array}$ & Ryan dan Deci (2000) \\
\hline & $\begin{array}{l}\text { EM4=mendapat pujian dari mahasiswa lain dan dosen jika aktif di } \\
\text { forum diskusi online SCELE }\end{array}$ & Ryan dan Deci (2000) \\
\hline & $\begin{array}{l}\text { EM5=Aktif menggunakan forum diskusi SCLE apabila gaya } \\
\text { mengajar (teachng style) dosen sesuai dengan harapan }\end{array}$ & Dikembangkan oleh peneliti \\
\hline
\end{tabular}

